\title{
Correction to: Plaque associated microglia hyper-secrete extracellular vesicles and accelerate tau propagation in a humanized APP mouse model
}

Kevin Clayton', Jean Christophe Delpech', Shawn Herron', Naotoshi Iwahara', Maria Ericsson², Takashi Saito ${ }^{3,4}$, Takaomi C. Saido ${ }^{4}$, Seiko Ikezu ${ }^{1}$ and Tsuneya Ikezu ${ }^{1,5,6^{*}}$

Correction to: Mol Neurodegeneration 16, 18 (2021)

https://doi.org/10.1186/s13024-021-00440-9

The original article [1] contained an error whereby the captions for Additional Files 2 and 3 were mistakenly inverted. This has since been corrected.

\begin{abstract}
Author details
'Departments of Pharmacology and Experimental Therapeutics, Boston University School of Medicine, Boston, MA 02118, USA. ${ }^{2}$ Department of Cell Biology, Harvard Medical School, Boston, MA 02115, USA. ${ }^{3}$ Department of Neurocognitive Science, Institute of Brain Science, Nagoya City University Graduate School of Medical Sciences, Nagoya, Aichi, Japan. ${ }^{4}$ Laboratory for Proteolytic Neuroscience, RIKEN Center for Brain Science, Wako, Saitama, Japan. ${ }^{5}$ Center for Systems Neuroscience, Boston University, Boston, MA 02215, USA. ${ }^{6}$ Department of Neuroscience, Mayo Clinic Florida, Jacksonville, FL 32224, USA.
\end{abstract}

Published online: 14 April 2021

\section{Reference}

1. Clayton $\mathrm{K}$, et al. Plaque associated microglia hyper-secrete extracellular vesicles and accelerate tau propagation in a humanized APP mouse model. Mol Neurodegeneration. 2021;16:18 https://doi.org/10.1186/s13024-021-00440-9.

The original article can be found online at https://doi.org/10.1186/s13024021-00440-9.

* Correspondence: Ikezu.tsuneya@mayo.edu

'Departments of Pharmacology and Experimental Therapeutics, Boston University School of Medicine, Boston, MA 02118, USA

${ }^{5}$ Center for Systems Neuroscience, Boston University, Boston, MA 02215, USA

(c) The Author(s). 2021 Open Access This article is licensed under a Creative Commons Attribution 4.0 International License, which permits use, sharing, adaptation, distribution and reproduction in any medium or format, as long as you give appropriate credit to the original author(s) and the source, provide a link to the Creative Commons licence, and indicate if changes were made. The images or other third party material in this article are included in the article's Creative Commons licence, unless indicated otherwise in a credit line to the material. If material is not included in the article's Creative Commons licence and your intended use is not permitted by statutory regulation or exceeds the permitted use, you will need to obtain permission directly from the copyright holder. To view a copy of this licence, visit http://creativecommons.org/licenses/by/4.0/ The Creative Commons Public Domain Dedication waiver (http://creativecommons.org/publicdomain/zero/1.0/) applies to the data made available in this article, unless otherwise stated in a credit line to the data. 